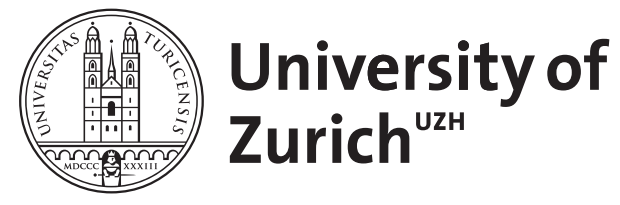

The Relative Importance of Type of Education and Subject Area: Empirical Evidence for Educational Decisions

\author{
Pfister, Curdin ; Tuor Sartore, Simone N ; Backes-Gellner, Uschi
}

DOI: https://doi.org/10.1108/EBHRM-05-2015-0019

Posted at the Zurich Open Repository and Archive, University of Zurich ZORA URL: https://doi.org/10.5167/uzh-136670

Journal Article

Accepted Version

Originally published at:

Pfister, Curdin; Tuor Sartore, Simone N; Backes-Gellner, Uschi (2017). The Relative Importance of Type of Education and Subject Area: Empirical Evidence for Educational Decisions. Evidence-based HRM: a Global Forum for Empirical Scholarship, 5(1):30-58.

DOI: https://doi.org/10.1108/EBHRM-05-2015-0019 


\section{Swiss Leading House Economics of Education - Firm Behaviour · Training Policies}

Working Paper No. 107

The Relative Importance of Type of Education and Subject Area: Empirical Evidence for Educational Decisions

Curdin Pfister, Simone Tuor Sartore, and Uschi Backes-Gellner 
Working Paper No. 107

\title{
The Relative Importance of Type of Education and Subject Area: Empirical Evidence for Educational Decisions
}

\author{
Curdin Pfister, Simone Tuor Sartore, and \\ Uschi Backes-Gellner
}

September 2015 (first version: February 2015)

A previous version of this Working Paper No. 107 was first published in February 2015 under the title "Earnings Returns to Different Educational Careers: The Relative Importance of Type vs. Field of Education".

This is an author-created, un-copyedited version of an article accepted for publication in Evidence-based HRM: a Global Forum for Empirical Scholarship.

Published as: "The Relative Importance of Type of Education and Subject Area: Empirical Evidence for Educational Decisions." Evidence-based HRM: a Global Forum for Empirical Scholarship, 5(2017)1: 30-58. By Curdin Pfister, Simone Tuor Sartore and Uschi Backes-Gellner. DOI: https://doi.org/10.1108/EBHRM-05-2015-0019

Die Discussion Papers dienen einer möglichst schnellen Verbreitung von neueren Forschungsarbeiten des Leading Houses und seiner Konferenzen und Workshops. Die Beiträge liegen in alleiniger Verantwortung der Autoren und stellen nicht notwendigerweise die Meinung des Leading House dar.

Disussion Papers are intended to make results of the Leading House research or its conferences and workshops promptly available to other economists in order to encourage discussion and suggestions for revisions. The authors are solely responsible for the contents which do not necessarily represent the opinion of the Leading House.

The Swiss Leading House on Economics of Education, Firm Behavior and Training Policies is a Research Program of the Swiss State Secretariat for Education, Research, and Innovation (SERI). 


\title{
The Relative Importance of Type of Education and Subject Area: Empirical Evidence for Educational Decisions
}

\begin{abstract}
Purpose - The purpose of this paper is to provide empirical evidence for individual educational investment decisions and to investigate the relative importance of two factors, the type of education (vocational vs. academic) and subject area (e.g., commercial or health), in determining variance in earnings.

Design/methodology/approach - Using a sample of 1200 individuals based on the 2011 Swiss Adult Education Survey, Mincer-type earnings equations are estimated. The variance in earnings is decomposed with respect to the two factors mentioned above, which allows to quantify the relative contributions of type of education and subject area to variance in earnings. Findings - The results of the variance decomposition show that subject area explains nearly twice the variance in earnings compared with that explained by type of education.

Social implications - As results show that earnings variance — and thereby risk - relate more to subject area than to type of education, this study suggests that for individuals caring about the risk of their educational decision the selection of a specific subject area is more relevant than the choice between vocational and academic tracks; in addition, educational policies as part of HRM policies should devote as much attention to the choice of subject areas as to vocational or academic education. This is especially important for companies or countries planning to introduce or to extend vocational education as part of their human resources strategies.
\end{abstract}

Originality/value - This study is the first to show whether earnings vary more by type of education or by subject area.

Keywords Variance Decomposition, Vocational vs. Academic Education, Subject Area, Returns to Education

Paper type Research paper 


\section{Introduction}

This paper provides evidence based support for educational investments and focuses on the variance of returns rather than the average returns, which have been analyzed extensively in the past. Returns and variance reflect two important aspects of educational investments: profitability and riskiness. In determining variance in earnings, this paper investigates for the first time the relative importance of two factors, the type of education (vocational vs. academic) and the subject area (e.g., commercial or health).

Returns as well as variance differ with respect to two factors. The first factor refers to the type of education and distinguishes between vocational and academic education. The second factor refers to the subject area and distinguishes among fields of education, e.g., commercial, health, STEM (science, technology, engineering and math), and social \& service. Studies investigating returns to education show mixed results with respect to type of education. On the one hand, previous research finds that academic education leads to higher earnings returns than vocational education (Conlon, 2005; Dearden et al., 2000; Heijke and Koeslag, 1999). On the other hand, results from countries with stronger vocational educational systems show reasonable - and in some cases even higher-earnings returns to vocational education (Tuor and Backes-Gellner, 2010; Wolter and Weber, 1999). Regarding subject area, results on returns to education are consistent across studies and indicate that the most profitable fields are engineering, health, and business and that the least profitable are education, social sciences, and humanities (Altonji et al., 2012; Finnie and Frenette, 2003; Rumberger and Thomas, 1993; Thomas, 2000; Thomas and Zhang, 2005). Only one study, Glocker and Storck (2014), focuses on both factors (type of education and subject area) and finds that university education is not always the most profitable path. ${ }^{1}$ Thus, regarding returns to educational investments, previous research shows that both type of education and subject area are related to earnings.

In comparison to returns to education, much less empirical evidence is available regarding the risk associated with human capital investments (Dickson and Harmon, 2011). However, the risk, or more precisely the variance in earnings has recently received considerable attention and is now the focus of an increasing number of studies (e.g., Hartog and Vijverberg, 2007 or Bonin et al., 2007). Regarding the type of education, Koerselman and Uusitalo (2014) find that, after accounting for returns and risk, university graduates are in a much better position than are

\footnotetext{
${ }^{1}$ Glocker and Storck (2014) use the German Micro Census to analyze the earnings risk and returns on investments in 70 fields of education, distinguishing between vocational and academic educations. Their results reveal heterogeneous returns, and in some fields, vocational education is more profitable than academic education. However, they fail to focus on the variance of these returns.
} 
vocational high school graduates. Regarding subject area, Christiansen et al. (2007) focus on the risk-return properties of human capital investments and find strong heterogeneity in returns and returns per unit of risk across fields. Thus far, no study reveals the extent to which these two factors contribute to the variance in earnings.

In this paper, we focus on both factors simultaneously and examine the relative importance of type of education and subject area for the variance in earnings. To do so, we decompose the variance in earnings to quantify the separate contribution of each of the two factors to the variance in earnings. Hence, we show the importance of these two factors in determining subsequent earnings.

To quantify the effect of each factor, we proceed in two steps. In the first step, we estimate ordinary least squares (OLS) regressions in the form of Mincer-type earnings equations. Instead of a continuous variable "years of schooling," we create dummy variables for type of education and subject area. For type of education, we distinguish among purely vocational, purely academic, and mixed education, i.e., individuals who combine vocational and academic educations. For subject area, we form the following five categories: (1) commercial, (2) health, (3) STEM, (4) social \& service, and (5) combined subject areas, i.e., individuals who combine different subject areas. In the second step, to analyze the importance of these two educational factors in determining the variance in earnings, we focus on the variance of these returns to type of education and to subject areas and compute the variance decomposition. This variance decomposition allows us to quantify the separate contribution of each educational choice variable to variance in earnings.

To estimate the relative effect of the two educational factors, we use the 2011 Swiss Adult Education Survey (CH-AES 2011) and construct a sample of approximately 1200 individuals, all of whom have a tertiary educational degree. These individuals are all highly educated and therefore consist a rather homogenous group. The results of the Mincer-type earnings equations show that both type of education and subject area have statistically significant impacts on returns to education. Regarding the type of education, academic and mixed educations yield higher returns than vocational education. Regarding subject area, commercial is the most profitable field, whereas the returns to social \& service fields constitute the other side of the spectrum. The results of the variance decomposition show that $9 \%$ of the explained variance in earnings is attributable to the type of education, whereas nearly $17 \%$ is attributable to the subject area, that is, subject area explains nearly double the variance in earnings. 
Our findings show that earnings relate more to subject area than to type of education. Hence, as the decision between vocational and academic education is less relevant than the choice of a specific field, policy discussions on the educational system should devote at least as much attention to the choice of subject area as to the type of education. In addition, given the favorable returns observed for mixed educational careers, the permeability of educational systems should also be discussed.

\section{Literature Review}

Numerous studies focus on the profitability of human capital investments. Studies on the effect of type of education on earnings demonstrate the importance of comparing vocational and academic educations and thereby the potential productivity differences resulting from one year of academic education vs. one year of vocational education and training rather than considering years of schooling. Dearden et al. (2000) use different data sources from the United Kingdom and find that, for a given educational level, returns to academic qualifications are higher compared with vocational qualifications. Similar results have been observed by Conlon (2005) for the United Kingdom and by Heijke and Koeslag (1999) for the Netherlands.

However, the results on the effects of vocational and academic educations on earnings are mixed in European countries (Ryan, 2001). Results from countries with stronger vocational education systems show that vocational education is favorable in terms of monetary and nonmonetary outcomes and - in some cases - even preferable to academic education. For example, Wolter and Weber (1999) calculate the returns to different types of education in the form of lifetime income in Switzerland, a country with a strong focus on vocational education. They conclude that any type of post-compulsory education is worthwhile. Moreover, they find no significant differences across types of post-compulsory education. Other studies show that vocational education is favorable in terms of monetary and non-monetary outcomes (see, e.g., Geel and Backes-Gellner, 2011; Tuor and Backes-Gellner, 2010). Thus, distinguishing between academic and vocational paths when examining returns to education is clearly important in European educational systems with strong vocational components.

Regarding subject area, the empirical results are more consistent. Rumberger and Thomas (1993) measure the impact of field of education, school quality, and educational performance on earnings in the United States. They find evidence that all types of qualitative factors have an influence. Regarding the field of education, engineering and health yield the highest gains, followed by science and math, and business. The social sciences and humanities, along with 
education, yield the lowest returns. Similar results are observed by Thomas (2000) and Thomas and Zhang (2005) for the U.S. and by Finnie and Frenette (2003) for Canada. Thomas (2000) analyzes the effect of college quality, academic performance and college major on the initial earnings and debt ratios of U.S. college graduates. Regarding field of education, i.e., college major, the results are identical: engineering and health-related majors yield the highest returns, whereas education and humanities are the least lucrative fields. Thomas and Zhang (2005) measure the impact of college quality and academic major on earnings for a representative cohort receiving a baccalaureate degree in 1993. They find significant variation across different types of tertiary academic degrees, observing the highest returns for business, engineering, and health.

Finnie and Frenette (2003) analyze differences in earnings by field of study for three cohorts of bachelor's degree holders in Canada. Among other results, they find the highest returns for health and engineering and the lowest returns for the social sciences and humanities; these results are robust to different sets of control variables. Finally, Altonji et al. (2012) present an overview of selected papers on returns to field of study and conclude that estimates are consistent across fields and over time. The results show a high premium for engineering, followed by science and business. Again, the social sciences, humanities and education fields yield relatively low monetary returns.

Studies that focus on risk are less numerous; the few studies focusing on this aspect show that risk is an important aspect of human capital investment (see, e.g., Hartog 2011). Harmon, Hogan and Walker (2003) identify two causes of variation in returns to education: heterogeneity and risk. Heterogeneity refers to differing returns to education among individuals due to factors that are known by the individual but are unobservable to the econometrician, while risk refers to factors that are unknown to both the individual and the econometrician. Using UK Labour Force Survey data from 1993 to 2000, Harmon, Hogan and Walker (2003) estimate the standard deviation of returns among individuals and find high dispersion in returns to education. Regarding changes in mean return and dispersion over time, they do not find a trend. Schweri, Hartog and Wolter (2011) investigate expected wage risk directly measuring Swiss students' anticipated wage distributions and find evidence for a positive association between risk and expected median wage, i.e. evidence for a tradeoff between risk and return.

Two studies focus on the factors of type of education and subject area. The first study by Koerselman and Uusitalo (2014) focuses on the returns to and risk of human capital investments. Based on a 22-year panel obtained from Finnish register data, they calculate the 
mean, variance and skew of lifetime income for different educational levels and thereby distinguish between vocational and academic education. The results show that mean discounted lifetime earnings are much higher for university graduates than for vocational high school graduates. In addition, adjusting for variance and skew, i.e., accounting for risk, does not change the results.

The second study by Christiansen et al. (2007) argues that educational careers differ in terms of both returns and risk. As individuals have heterogeneous utilities regarding the risk of and returns to education, both the mean and the variance of a specific human capital investment influence their educational decisions. These authors therefore focus on the risk-return properties of human capital investments and find strong heterogeneity in returns and returns per unit of risk across fields. Although they focus on both the type and field of education, their study does not provide evidence on these two factors at the same level. For example, they compare an upper-secondary vocational education (Bank Office Clerk Apprenticeship) with a tertiary academic education (Master of Science in Economics). Their comparison of fields at the same level, a strategy to reduce potential ability bias, focuses only on individuals with a tertiary academic educational degree and excludes vocational education.

In sum, both the type of education and the subject area are important in determining the profitability and risk of human capital investments. Therefore, analyses focusing on the effect of education on earnings and on risk must account for the individual's entire educational career. In this study, we therefore focus on the individual's complete educational career and analyze the extent to which subsequent earnings vary with respect the two factors. We expect that subsequent earnings vary less with respect to type of education, as all individuals with a tertiary degree have acquired a substantial amount of human capital and are highly skilled workers, irrespective of whether they followed the academic or the vocational track. However, we expect that subsequent earnings vary more with respect to subject area, as the demand for and the returns to different fields vary in the labor market.

\section{Data, Sample and Variables}

To calculate the contributions of the two factors, type of education and subject area, to variance in earnings, we are interested in analyzing a country that offers vocational and academic education at the upper-secondary and tertiary levels and that provides detailed data on both the type of education and the subject area. The CH-AES 2011 is especially appropriate for our purposes. This survey is part of the Swiss Federal population census, which is completed 
by computer-assisted telephone interviewing. The CH-AES 2011 contains data on the labor market status, socioeconomic background, and formal and non-formal education of 13,000 individuals. The CH-AES 2011 covers the individual's entire educational career. Moreover, it makes available detailed descriptions of the type and field of all educational choices that an individual has made, so the survey is particularly appropriate for our study. To improve understanding of our variables, we first describe the Swiss educational system in which academic and vocational educations coexist at the upper-secondary and tertiary levels. ${ }^{2}$

\section{The Swiss Educational System}

Figure 1 presents the Swiss educational system and shows that the system provides vocational and academic educations at the upper-secondary and tertiary levels. The system allows for permeability between and within the two levels. ${ }^{3}$ A detailed description of the Swiss educational system can be found in the Appendix.

\section{Figure 1: The Swiss Educational System}

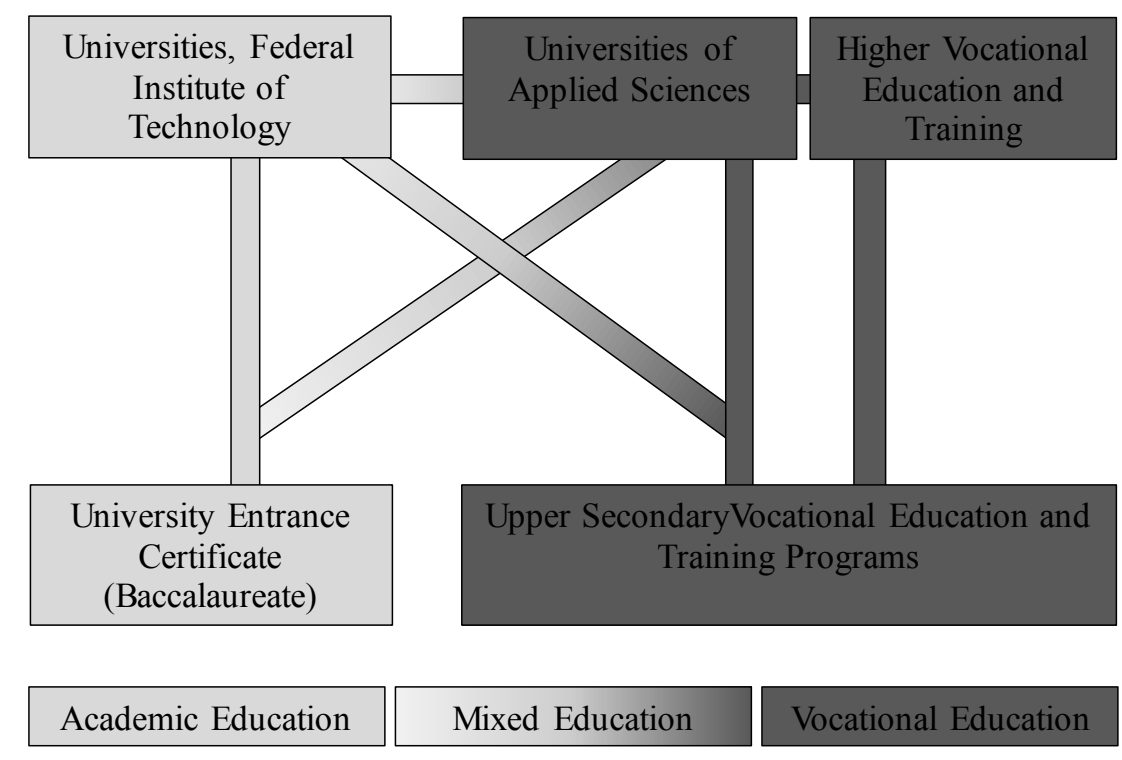

Source: Own illustration, based on Swiss Coordination Centre for Research in Education (SCCRE) (2007, 2010, 2014).

\footnotetext{
${ }^{2}$ All information regarding the Swiss educational system comes from Swiss Coordination Centre for Research in Education (SCCRE) (2007), SCCRE (2010), SCCRE (2014), and Federal Office for Professional Education and Technology (OPET) (2009).

${ }^{3}$ Universities of Teacher Education and upper-secondary specialized schools are not included in the illustration, as these institutions are not relevant to our analysis.
} 
After nine years of compulsory schooling, students aged approximately 15 or 16 choose between vocational and academic upper-secondary educations. Approximately $60 \%$ of all Swiss students choose an upper-secondary vocational education and training (VET) program (SCCRE 2010, p. 112). These programs combine on-the-job training in the form of a paid apprenticeship in a host company with theoretical instruction at school. Graduates receive an "Advanced Federal Certificate" and continue working as skilled workers within their respective occupational fields; they are employed by either the training company or a new one.

Individuals with upper-secondary vocational degrees have several options for tertiary education. On the one hand, they can continue to follow the vocational track because the Swiss educational system offers a variety of opportunities with different objectives. These opportunities comprise, among others, universities of applied sciences and higher vocational education and training institutions. ${ }^{4}$ On the other hand, individuals with upper-secondary vocational degrees can change to the academic tertiary education track (i.e., universities or federal institutes of technology) if they fulfill certain requirements.

In contrast to other Western countries, only approximately $20 \%$ of Swiss students completing compulsory schooling actually choose the academic track, i.e., obtain a University Entrance Certificate (baccalaureate) (SCCRE 2010, p. 17). This baccalaureate allows its holder unrestricted access to all tertiary academic institutions in Switzerland, i.e., universities and federal institutes of technology. Moreover, if they complete a traineeship in their intended field of study, individuals with a baccalaureate degree also have access to universities of applied science.

\section{Explanatory and Dependent Variables}

To measure the contributions of type of education and subject area to variance in earnings, we create two explanatory variables as follows. For the type of education variable, we distinguish among purely academic (light gray in Figure 1), purely vocational (dark gray), and mixed (light and dark gray) educational careers. Purely academic educational paths exclusively include academic components, i.e., baccalaureate, university, or federal institute of technology

\footnotetext{
${ }^{4}$ Following the Federal Act on Funding and Coordination of the Swiss Higher Education Sector (HFKG) of September 30, 2011, the Swiss Confederation fosters a higher education sector comprising different but equivalent types of higher education institutions. These are conventional universities and federal institutes of technology, universities of teacher education, and universities of applied sciences. The HFKG states that these universities of applied sciences provide practical studies and applied research and development. Studying at a university of applied science allows students to perform activities in specific professions requiring the use of research findings and methods. Graduates obtain a qualification that enables them to work in a given profession. For further information, see SCCRE (2014) and Hoeckel et al. (2009).
} 
studies. Purely vocational educational paths exclusively include vocational components, i.e., any type of VET program, studies at a university of applied sciences, or a degree from a higher VET institution.

Mixed educational paths include both academic and vocational components. ${ }^{5}$ On the one hand, mixed careers can begin either in an upper-secondary academic institution and end in a tertiary vocational institution, e.g., a baccalaureate plus a traineeship plus studies at a university of applied sciences. On the other hand, such careers can begin in an upper-secondary vocational institution and end in a tertiary academic institution, e.g., a VET program plus, having fulfilled the special requirements, studies at a university. Theoretically, numerous combinations of mixed careers are possible. However, we focus on the most common combinations and include only individuals who switch only once between vocational and academic education.

For the subject area variable, we follow the literature (see, e.g., Altonji et al., 2012, Finnie and Frenette, 2003, or Rumberger and Thomas, 1993, for a literature overview of different classifications) and distinguish among five groups. We create dummy variables for commercial, health, STEM, and social \& service areas of study. Finally, we create a fifth group for individuals who combine subject areas, combined subject areas. ${ }^{6}$

Our dependent variable, $\ln$ (earnings), is the logarithm of annual gross income from earnings. For individuals who work part-time, we calculate the equivalent full-time earnings. In addition, to control for potential part-time effects, we include a part-time dummy (Part-time).

Finally, in addition to experience ${ }^{7}$, we include the following set of control variables ${ }^{8}$ in our estimation: a dummy for being male (Men), a dummy for being self-employed, dummies for linguistic region (French, Italian and German, with German as the reference group), and for being foreign (Foreign), i.e., not a Swiss citizen. ${ }^{9}$

\footnotetext{
${ }^{5}$ Regarding the type of education factor, we include the category for mixed education types because previous research shows that combining vocational and academic education might lead to superior outcomes (e.g., Kang and Bishop, 1989; Bishop and Mane, 2004; Tuor and Backes-Gellner, 2010). In addition, regarding the subject area factor, we include the category for combined subject areas because previous research shows that combining fields might lead to differing outcomes (e.g., Del Rossi and Hersch, 2008; Hemelt, 2010).

${ }^{6}$ Table A1 shows further information regarding the classification of subject areas.

${ }^{7}$ The CH-AES 2011 provides no information on experience or experience squared. We therefore use the number of years since the last completed level of education as a proxy. To measure the share of variance in earnings explained by experience, we create seven dummies: The first dummy comprises individuals with labor market experience of 0 to 2 years; the second of 3 to 5 ; the third of 6 to 8 ; the fourth of 9 to 13; the fifth of 14 to 18 ; the sixth of 19 to 25 ; and the seventh of 26 and more years.

${ }^{8}$ Pereira and Martins (2001) emphasize that the inclusion of covariates related to education leads to a decrease in the coefficient of education, i.e., to biased returns to education. We therefore include only control variables that are assumed independent of educational choice.

${ }^{9}$ These control variables refer to factors that imply differences in earnings. For differences in earnings between women and men, see, e.g., Janssen et al. (2015); for differences between self-employed and employed individuals,
} 


\section{Sample}

Our sample consists of employed individuals between 25 and 65 years old who have completed any type of tertiary education. ${ }^{10}$ As these individuals are all highly educated, the sample allows comparing return and risk patterns of a rather homogenous group. Differences therefore refer to the factors type of education and subject area, and not to the level of education, i.e. whether the individual has a longer or a shorter educational career. This subsample represents a large group of the Swiss population; following the Federal Statistical Office, $40 \%$ of the population living in Switzerland and of age 25 to 64 has a tertiary level educational degree. $^{11}$

We exclude all individuals whose educations are not attributable to vocational or to academic education (such as teachers). Furthermore, we exclude all individuals who switched more than once between the vocational and academic educational tracks, as they are very rare and special cases. In addition, we exclude individuals in the armed forces. Finally, following Gerfin et al., 2003, we drop the highest and the lowest percentile of the earnings distribution. We thus focus on a quite homogeneous sample, as all individuals holding a tertiary educational degree have acquired a substantial amount of human capital and are highly skilled workers. Our final sample contains 1161 individuals. $^{12}$

The descriptive statistics in Table 1 show a mean of $\ln$ (earnings) of 11.5058 , corresponding to an annual income of approximately $100,000 \mathrm{CHF}$. These statistics show that $34 \%$ of the individuals in our sample follow the purely vocational track, approximately $43 \%$ have a purely academic educational career, and approximately 23\% have a mixed educational career. Regarding subject area, commercial and STEM fields contain the largest number of individuals: commercial contains 33\% and STEM 26\%. The health and combined subject areas both contain approximately $16 \%$ of all individuals with a tertiary-level degree. The smallest group, at $9 \%$, is social \& service.

see, e.g., Backes-Gellner and Moog (2013), Backes-Gellner et al. (2010), or Tuor and Backes-Gellner (2010); for differences by linguistic region, see, e.g., Eugster et al. (2011).

${ }^{10}$ The lower bound of the age restriction implies that individuals most likely have completed their educations. The upper bound of the age restriction implies that individuals who are retired, i.e., individuals older than 65, are excluded.

11 The information is available from the Swiss Federal Statistical Office, accessed at http://www.bfs.admin.ch/bfs/portal/de/index/themen/15/17/blank/01.indicator.406101.4016.html (September 2015).

${ }^{12}$ Nearly $60 \%$ of the 13,000 individuals are employed and provide information regarding their earnings. Of these individuals, $35 \%$ have a tertiary educational degree. 


\begin{tabular}{|c|c|c|c|c|c|}
\hline Variable & $\mathrm{N}$ & Mean & Std. Dev. & Min & $\operatorname{Max}$ \\
\hline $\ln$ (earnings) & 1161 & 11,5058 & 0,4938 & 9,741 & 13,082 \\
\hline \multicolumn{6}{|l|}{ Type of Education } \\
\hline Vocational & 1161 & 0,3351 & 0,4722 & 0 & 1 \\
\hline Academic & 1161 & 0,4332 & 0,4957 & 0 & 1 \\
\hline Mixed & 1161 & 0,2317 & 0,4221 & 0 & 1 \\
\hline \multicolumn{6}{|l|}{ Subject Area } \\
\hline Commercial & 1161 & 0,3282 & 0,4697 & 0 & 1 \\
\hline Health & 1161 & 0,1628 & 0,3693 & 0 & 1 \\
\hline STEM & 1161 & 0,2618 & 0,4398 & 0 & 1 \\
\hline Social \& Service & 1161 & 0,0930 & 0,2906 & 0 & 1 \\
\hline Combined Subject Areas & 1161 & 0,1542 & 0,3613 & 0 & 1 \\
\hline \multicolumn{6}{|l|}{ Covariates } \\
\hline Men & 1161 & 0,5090 & 0,5001 & 0 & 1 \\
\hline German & 1161 & 0,5736 & 0,4948 & 0 & 1 \\
\hline French & 1161 & 0,3635 & 0,4812 & 0 & 1 \\
\hline Italian & 1161 & 0,0629 & 0,2428 & 0 & 1 \\
\hline Self Employed & 1161 & 0,0999 & 0,3000 & 0 & 1 \\
\hline Foreign & 1161 & 0,2377 & 0,4259 & 0 & 1 \\
\hline Part-time & 1161 & 0,3333 & 0,4716 & 0 & 1 \\
\hline Exp: $0-2$ & 1161 & 0,1309 & 0,3375 & 0 & 1 \\
\hline Exp: 3-5 & 1161 & 0,1413 & 0,3484 & 0 & 1 \\
\hline Exp: 6-8 & 1161 & 0,1602 & 0,3670 & 0 & 1 \\
\hline Exp: 9-13 & 1161 & 0,1559 & 0,3629 & 0 & 1 \\
\hline Exp: $14-18$ & 1161 & 0,1344 & 0,3412 & 0 & 1 \\
\hline Exp: 19-25 & 1161 & 0,1344 & 0,3412 & 0 & 1 \\
\hline Exp: $26+$ & 1161 & 0,1430 & 0,3502 & 0 & 1 \\
\hline
\end{tabular}

Source: Own calculations, based on CH-AES 2011. 


\section{Estimation Strategy}

To quantify the contributions of type of education and subject area to variance in earnings, we proceed in two steps. In the first step, we estimate OLS regressions in the form of Mincertype earnings equations, including variables for schooling, experience and experience squared. However, instead of the continuous variable years of schooling, we use dummies that represent our two factors, type of education and subject area. The basic estimation equation is the following:

$$
\text { Equation (1) } \ln (\text { earnings })=T^{\prime} \alpha+S^{\prime} \beta+C V^{\prime} \gamma+\varepsilon \text {, }
$$

where $T$ refers to type of education and $S$ to subject area. For type, we distinguish among purely vocational, purely academic and mixed educations, i.e., individuals who combine vocational and academic educations. For subject area, we distinguish among our five categories: (1) commercial, (2) health, (3) STEM, (4) social \& service, and (5) combined subject areas. Finally, we include our set of control variables.

In the second step, we compute the variances of the dependent variable, $\ln$ (earnings), of the coefficients of the two independent variables of interest, type of education and subject area, and of the coefficients of our set of control variables. ${ }^{13}$ Using Equation (1), the variance of observed ln(earnings) can be decomposed as follows:

$$
\begin{aligned}
& \text { Equation (2) } \operatorname{Var}(\ln (\text { earnings })) \\
& \qquad \begin{aligned}
= & \operatorname{Var}(T \hat{\alpha})+\operatorname{Var}(S \hat{\beta})+\operatorname{Var}(\operatorname{CV} \hat{\gamma})+2 \operatorname{Cov}(T \hat{\alpha}, S \hat{\beta})+2 \operatorname{Cov}(T \hat{\alpha}, C V \hat{\gamma}) \\
& +2 \operatorname{Cov}(S \hat{\beta}, C V \hat{\gamma})+\operatorname{Var}(\hat{\varepsilon}) .
\end{aligned}
\end{aligned}
$$

We then report the ratio of variance in earnings explained by the type of education variable and that explained by the subject area variable: First, we calculate the sum of the variance in

\footnotetext{
${ }^{13}$ We replace each term in Equation (2) with the respective sample analogue to obtain a feasible version of the decomposition. For the variance of $\ln$ (earnings), we calculate:

$s_{y y}=\frac{1}{n-1} \sum\left(y_{i}-\bar{y}\right)^{2}$, where $\bar{y}=\frac{1}{n} \sum y_{i}$.

For the variance of the coefficients of type of education and subject area, we calculate:

$s_{T T}=\frac{1}{n-1} \sum\left(\mathrm{T} \hat{\alpha}_{i}-\mathrm{T} \hat{\bar{\alpha}}\right)^{2}$

$s_{F F}=\frac{1}{n-1} \sum\left(\mathrm{S} \hat{\beta}_{i}-\mathrm{S} \hat{\bar{\beta}}\right)^{2}$.

Finally, for the covariance between type of education and subject area, we calculate:

$s_{T F}=\frac{1}{n-1} \sum\left(\mathrm{T} \hat{\alpha}_{i}-\mathrm{T} \hat{\bar{\alpha}}\right)\left(\mathrm{S} \hat{\beta}_{i}-\mathrm{S} \hat{\bar{\beta}}\right)$.
} 
$\ln$ (earnings) explained by type of education, subject area, experience and control variables. Second, we divide the respective variance and covariance components by this sum of explained variance. This variance decomposition allows us to quantify the separate contributions of type of education and subject area to variance in earnings.

\section{Results}

The first step in quantifying the impact of type of education and subject area on variance in earnings implies the use of Mincer-type earnings equations. Table 2 reports the results of the earnings equation (Equation (1)). Specifications (1) and (2) represent separate regressions of the dummies for type of education and experience on $\ln$ (earnings) and the dummies for subject area and experience, respectively. Specification (3) comprises dummies for both factors, as well as experience, and indicates that results for the type of education factor are robust to the inclusion of the subject area factor. ${ }^{14}$

In addition to all educational choice variables, specification (4) includes our set of control variables for being male, linguistic region, self-employment, foreign nationality and working part-time. Regarding type of education, the results indicate higher returns for academic and mixed educations. Both are statistically significant at the one-percent level. The difference between them is statistically insignificant. Regarding subject area, individuals in the STEM fields earn $8.8 \%$ less and individuals in the social \& service fields $30.0 \%$ less than do individuals in the commercial fields; these differences are significant. However, the health and mixed fields show no significant differences in returns compared with the commercial fields. Finally, the results regarding experience and control variables are in line with previous research.

\footnotetext{
${ }^{14}$ Specification 3 shows that the returns for purely academic and mixed educational careers slightly increase after the inclusion of the factor subject area. The reason might be that these individuals having a purely academic or a mixed educational career are more likely in the low-paying subject areas STEM and Social \& Service.
} 


\section{$\ln$ (earnings)}

Spec. 1

Spec. 2

Spec. 3

Spec. 4

\begin{tabular}{|c|c|c|c|c|}
\hline Vocational & Base Group & & Base Group & Base Group \\
\hline Academic & $\begin{array}{l}0.0703 * * \\
(0.0324)\end{array}$ & & $\begin{array}{c}0.1122 * * * \\
(0.0345)\end{array}$ & $\begin{array}{c}0.1437 * * * \\
(0.0344)\end{array}$ \\
\hline Mixed & $\begin{array}{c}0.0483 \\
(0.0381)\end{array}$ & & $\begin{array}{c}0.0759 * * \\
(0.0380)\end{array}$ & $\begin{array}{c}0.1062 * * * \\
(0.0375)\end{array}$ \\
\hline Commercial & & Base Group & Base Group & Base Group \\
\hline Health & & $\begin{array}{c}-0.0890 * * \\
(0.0421)\end{array}$ & $\begin{array}{c}-0.1047 * * \\
(0.0422)\end{array}$ & $\begin{array}{l}-0.0245 \\
(0.0421)\end{array}$ \\
\hline STEM & & $\begin{array}{l}-0.0402 \\
(0.0365)\end{array}$ & $\begin{array}{l}-0.0625^{*} \\
(0.0371)\end{array}$ & $\begin{array}{c}-0.0883 * * \\
(0.0364)\end{array}$ \\
\hline Social \& Service & & $\begin{array}{c}-0.3221 * * * \\
(0.0515)\end{array}$ & $\begin{array}{c}-0.3512 * * * \\
(0.0521)\end{array}$ & $\begin{array}{c}-0.3001 * * * \\
(0.0511)\end{array}$ \\
\hline Combined Subject Areas & & $\begin{array}{l}-0.0769 * \\
(0.0429)\end{array}$ & $\begin{array}{l}-0.0459 \\
(0.0438)\end{array}$ & $\begin{array}{l}-0.0227 \\
(0.0424)\end{array}$ \\
\hline Experience & Included & Included & Included & Included \\
\hline Control Variables & & & & Included \\
\hline Constant & $\begin{array}{c}11.2239 * * * \\
(0.0434)\end{array}$ & $\begin{array}{c}11.3468 * * * \\
(0.0437)\end{array}$ & $\begin{array}{c}11.2890 * * * \\
(0.0473)\end{array}$ & $\begin{array}{c}11.2411 * * * \\
(0.0495)\end{array}$ \\
\hline Adjusted R-squared & 0.0636 & 0.0902 & 0.0971 & 0.1631 \\
\hline R-squared & 0.0700 & 0.0981 & 0.1064 & 0.1761 \\
\hline $\mathrm{N}$ & 1161 & 1161 & 1161 & 1161 \\
\hline Prob $>F$ & 0.000 & 0.000 & 0.000 & 0.000 \\
\hline
\end{tabular}


The second step in quantifying the effect of type of education and subject area on variance in earnings is a variance decomposition regarding the two factors. We calculate the extent to which type of education and subject area contribute to total variance in ln(earnings). The first column of Table 3 follows Equation (2) and reports the variance in $\ln$ (earnings) explained by the respective variance and covariance components. The second column reports these components' relative shares of variance in $\ln$ (earnings) explained by the model. We calculate these shares by dividing the respective variance or covariance component by the sum of the variance explained by our model.

The first row of Table 3 shows that the variance of $\ln$ (earnings) is approximately 0.2438 . Our explanatory variables explain $17.61 \%$ of the variance in $\ln$ (earnings), implying that our model has an R-squared of .1761.

The second row depicts the variance in the three dummies for type of education, vocational, academic and mixed, and the third row reports the five dummies for subject area, commercial, health, STEM, social \& service, and mixed fields. The variance for type of education is 0.0040 , and the share of the explained variance in $\ln$ (earnings) approximately $9 \%$. The variance for subject area equals 0.0072 , and the respective share of the explained variance in $\ln$ (earnings) approximately $9 \%$. The covariance between type and field of education equals -0.0023 and accounts for approximately $5 \%$ of the explained variance.

Rows four through nine report the variances and relative shares of experience and our set of control variables. The results for the dummies for experience and the dummy for gender are the largest: The variance equals 0.0140 for experience and 0.0102 for gender. Approximately $33 \%$ of the variance in $\ln$ (earnings) is attributable to experience, and approximately $24 \%$ is attributable to gender. The shares of linguistic region, self-employment, being foreign and working part-time explained between $3 \%$ and $5 \%$ of variation in earnings.

In summary, the subject area factor accounts for nearly twice the explained variance in earnings as that attributable to the type of education factor. 


\begin{tabular}{lccc}
\hline & Variance & $\begin{array}{c}\text { Share of total } \\
\text { Variance }\end{array}$ & $\begin{array}{c}\text { Share of explained } \\
\text { Variance }\end{array}$ \\
\hline \hline & & & \\
Total Variance of ln(Earnings) & 0.2438 & $100 \%$ & $100 \%$ \\
Explained Variance of ln(Earnings) & 0.0429 & $17.61 \%$ & \\
& & & \\
Components of Variance: & & & $9.36 \%$ \\
Type of Education & 0.0040 & $1.65 \%$ & $16.72 \%$ \\
Subject Area & 0.0072 & $2.94 \%$ & \\
& & & $23.86 \%$ \\
Gender (Male) & 0.0102 & $4.20 \%$ & $4.48 \%$ \\
Linguistic Region & 0.0019 & $0.79 \%$ & $0.37 \%$ \\
Self-Employed & 0.0002 & $0.07 \%$ & $4.04 \%$ \\
Foreign & 0.0017 & $0.71 \%$ & $3.22 \%$ \\
Part-Time & 0.0014 & $0.57 \%$ & $32.68 \%$ \\
Experience & 0.0140 & $5.75 \%$ & \\
\hline Soure: Own & & & \\
\hline
\end{tabular}

Source: Own calculations, based on CH-AES 2011. Table A3 shows the results for the respective covariance.

\section{Subsample Analysis}

In the next step, we focus on two important aspects. First, we consider subsamples for women and for men to determine whether the results differ with respect to gender. Second, to account for differences among subgroups constructed on the basis of the two factors, we calculate the explained variance in earnings attributable to subject area within each type of education and the explained variance in earnings attributable to type of education within each subject area.

\section{Subsample Analysis: Gender}

The literature indicates that returns to education differ between women and men (see, e.g., Harmon, Oosterbeek, and Walker, 2003). We therefore estimate returns to type of education and subject area for subsamples of women and men. Tables A4.1 and A4.2 report the results of the earnings equations for women and men. The results from the earnings equations are similar for women and men. However, women appear to exhibit greater variance in returns to type of education, whereas men appear to exhibit greater variance in returns to field of education.

The results of the variance decomposition confirm these differences. Table 4 shows that variance in earnings is nearly identical between women and men. The decomposition results 
for women show that the variance in both type of education and subject area equals 0.057 . Hence, both type of education and subject area explain approximately $22 \%$ of the variance in earnings. In contrast, the decomposition results for men show a lower variance for type of education (0.0033) and a much higher variance for subject area (0.0188). Hence, less than $10 \%$ of the explained variance in earnings is attributable to type of education, whereas more than $35 \%$ of the explained variance in earnings is associated with subject area.

Consequently, the two factors differ between women and men. Whereas for women, both factors are equally important, for men, subject area is associated with considerably more variance in earnings than is type of education. ${ }^{15}$

Table 4: Variance Decomposition for Women and Men

\begin{tabular}{|c|c|c|c|c|c|c|}
\hline & \multicolumn{3}{|c|}{ Women } & \multicolumn{3}{|c|}{ Men } \\
\hline & Variance & $\begin{array}{c}\text { Share of } \\
\text { total }\end{array}$ & $\begin{array}{l}\text { Share of } \\
\text { explained }\end{array}$ & Variance & $\begin{array}{l}\text { Share of } \\
\text { total }\end{array}$ & $\begin{array}{l}\text { Share of } \\
\text { explained }\end{array}$ \\
\hline Total Variance of $\ln$ (Earnings) & 0.2277 & $100 \%$ & & 0.2258 & $100 \%$ & \\
\hline $\begin{array}{l}\text { Explained Variance of } \\
\ln \text { (Earnings) }\end{array}$ & 0.0252 & $11.07 \%$ & $100 \%$ & 0.0334 & $14.78 \%$ & $100 \%$ \\
\hline \multicolumn{7}{|l|}{ Components of Variance: } \\
\hline Type of Education & 0.0057 & $2.49 \%$ & $22.46 \%$ & 0.0033 & $1.45 \%$ & $9.83 \%$ \\
\hline Subject Area & 0.0057 & $2.50 \%$ & $22.56 \%$ & 0.0118 & $5.21 \%$ & $35.22 \%$ \\
\hline Linguistic Region & 0.0033 & $1.47 \%$ & $13.25 \%$ & 0.0017 & $0.77 \%$ & $5.24 \%$ \\
\hline Self-Employed & 0.0003 & $0.14 \%$ & $1.22 \%$ & 0.0000 & $0.02 \%$ & $0.10 \%$ \\
\hline Foreign & 0.0010 & $0.44 \%$ & $3.95 \%$ & 0.0023 & $1.01 \%$ & $6.81 \%$ \\
\hline Part-Time & 0.0010 & $0.44 \%$ & $3.95 \%$ & 0.0007 & $0.33 \%$ & $2.22 \%$ \\
\hline Experience & 0.0132 & $5.81 \%$ & $52.48 \%$ & 0.0168 & $7.44 \%$ & $50.33 \%$ \\
\hline
\end{tabular}

Source: Own calculations, based on CH-AES 2011. Table A5.1 and Table A5.2 show the results for the respective covariance.

The share of variance explained by linguistic region highly differs between women and men. One reason that women's earnings vary more with the linguistic region than men's earnings could be discriminatory social attitudes (see Janssen et al., 2015).

\footnotetext{
${ }^{15}$ The question of how differences in the joint distribution of education type and subject area are related to gender differences has to be answered by future research, as the number of cases in the cells is too small for further analyses.
} 


\section{Subsample Analysis: Type of Education and Subject Area}

Our baseline model does not account for interaction effects. In a last step, we therefore focus on differences among the subgroups constructed on the basis of the two factors: type of education and subject area.

First, we report the extent to which the subject area factor contributes to variance in earnings within each type of education. We estimate Mincer-type earnings regressions on subsamples of individuals with purely vocational educations, of individuals with purely academic educations, and of individuals with mixed educations. We then decompose the variance regarding subject area, experience, and our set of control variables and calculate the share of variance explained by the subject area factor.

Table A6 reports the results for the subject area factor within each type of education. The overall result of our baseline model remains unchanged: Returns are largest for the commercial fields and lowest for social \& service fields. ${ }^{16}$

Table 5 reports the respective variance decomposition within the three subsamples. The first row shows that the variance in ln(earnings) is lowest for individuals with purely vocational educations and highest for individuals whose educations are purely academic. Hence, individuals following a purely academic career face more variance in subsequent earnings than do individuals following a purely vocational career. The subject area factor has a variance of 0.0079 in the vocational subsample and of 0.0071 in the academic subsample. The share of explained variance equals $17 \%$ for individuals with purely vocational educations and $11 \%$ for individuals with purely academic educations. For individuals combining vocational and academic educations, the variance of the subject area factor equals 0.016 and is considerably higher than the variance of individuals focusing on one type of education. Similarly, the share of explained variance in earnings attributable to subject area is more than $30 \%$.

\footnotetext{
${ }^{16}$ Results in Table A6 do not point towards complementarities for individuals who just combine different types of education or who just combine different subject areas. However, further break downs of the cells suggest that those individuals who change their subject when they mix their type of education (like for example coming from a mechanical vocational training and then moving into an academic management education) might gain from complementarity effects. However, as cells become rather small with these breakdowns, further research is needed.
} 


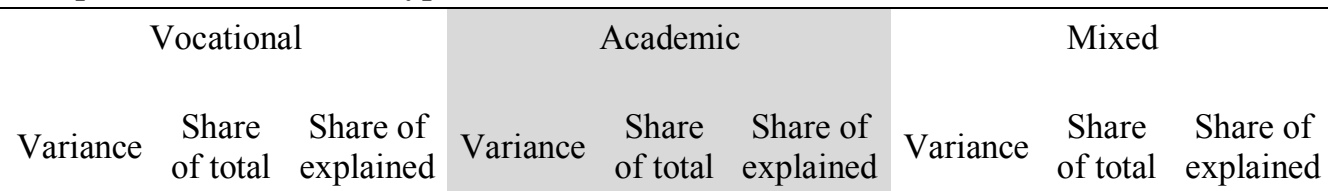

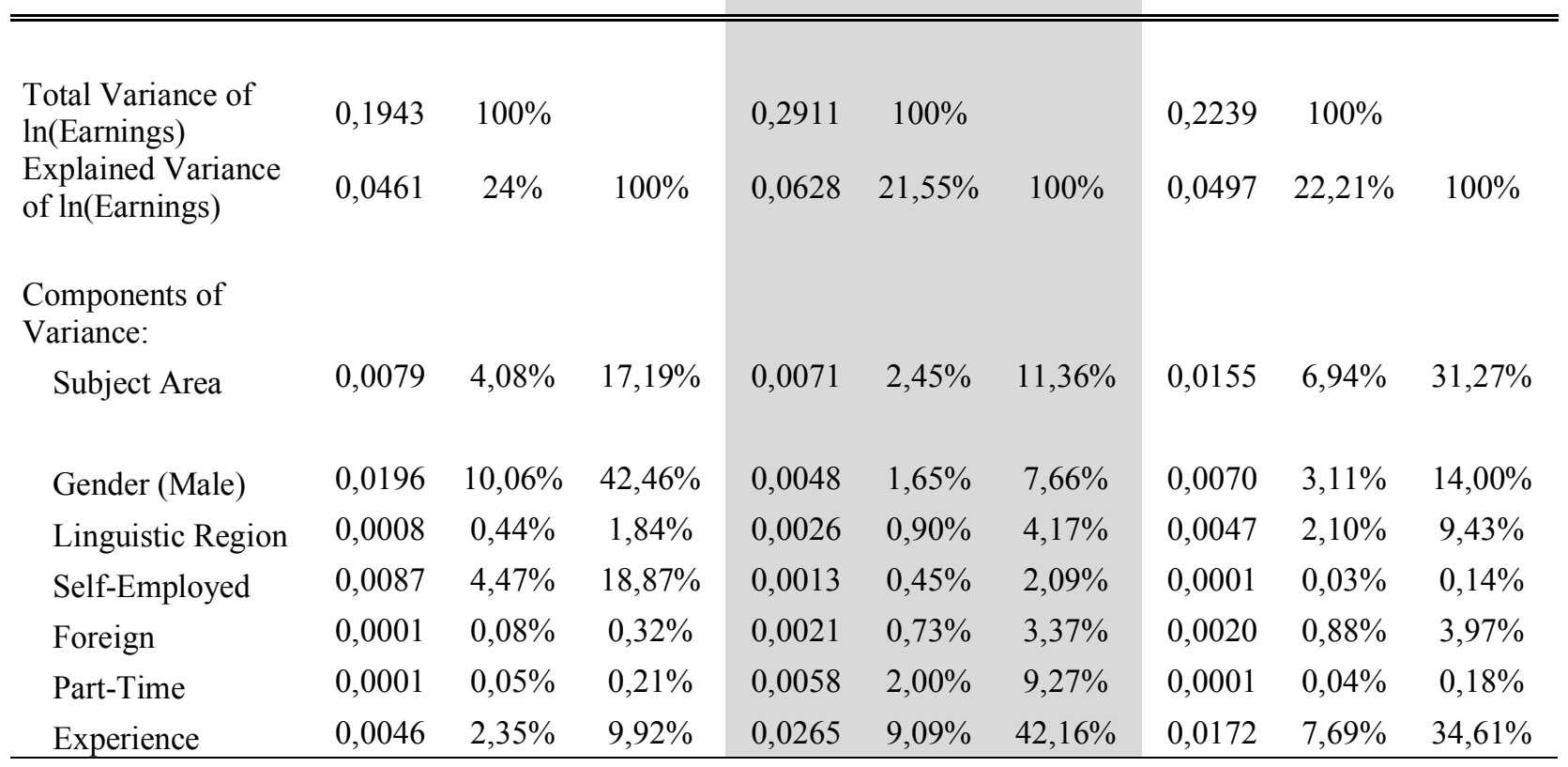

Source: Own calculations, based on CH-AES 2011. Table A7 shows the results for the respective covariance.

Second, we analyze the extent to which the type of education factor contributes to the variance in earnings within each subject area. We estimate earnings regressions on subsamples of individuals with degrees in the commercial, health, STEM, and social \& service fields and individuals with degrees in more than one subject area, that is, the combined subject areas category. We then perform a variance decomposition regarding type of education, experience and our control variables to identify the relative contribution of each component to the explained variance in earnings.

Table A8 reports the results for the type of education factor within each subject area. The overall result of the baseline model remains unchanged: Academic and mixed educations yield higher returns than vocational educations. However, for individuals who completed their educations within the commercial fields, the type of education is irrelevant.

Table 6 reports the variance decomposition for each of the five subsamples. The first row comprises the variance in $\ln$ (earnings) within each subsample and shows that, at values between 0.20 and 0.24 , they are lowest within the commercial, STEM and combined subject areas subsamples. The variance in earnings within the health and social \& service subsamples are considerably higher, with values of 0.28 and 0.31 , respectively. 
Table 6: Variance Decomposition within each Subject Area

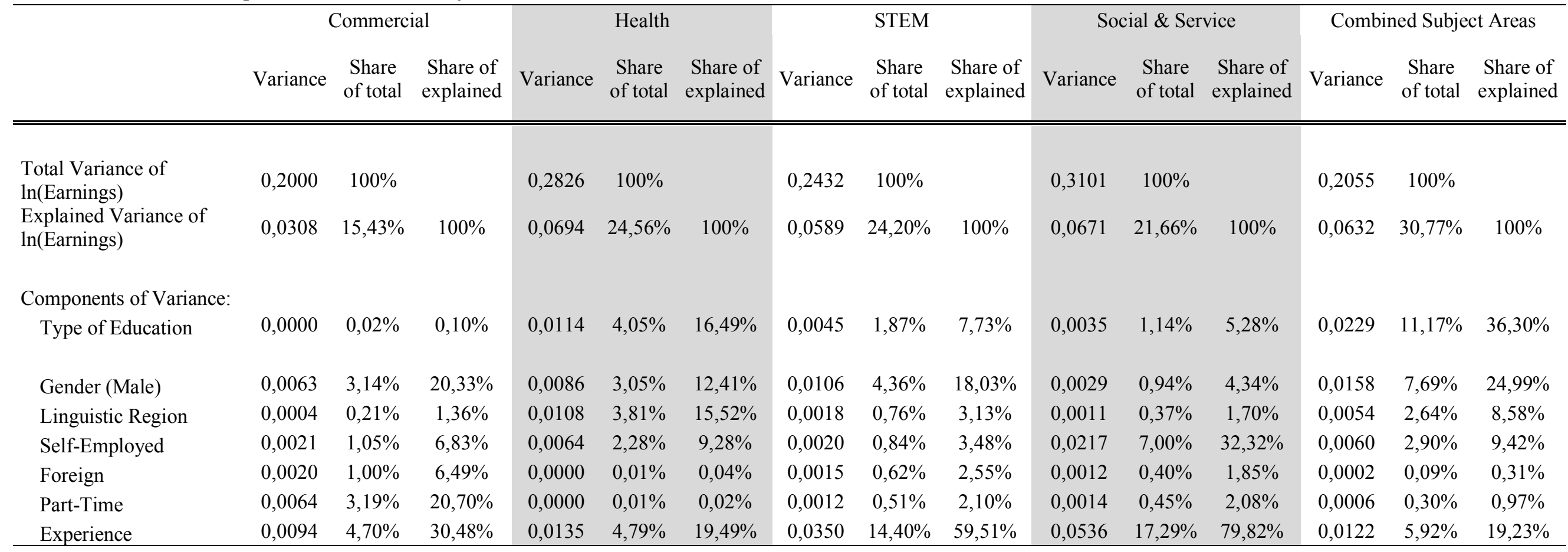

Source: Own calculations, based on CH-AES 2011. Table A9 shows the results for the respective covariance 
The second row reports the variance of the type of education factor within each subsample as well as its share of explained variance in earnings. Within the commercial subsample, the type of education factor exhibits a variance of 0.00003 , implying that it explains $0.1 \%$ of variance in earnings. Within STEM and social \& services fields, the variance is 0.0045 and 0.0035 , respectively, which equals shares of explained variance of $7.7 \%$ and $5.3 \%$. Within the health and mixed field subsamples, the variance of the type of education is much higher and equals 0.011 and 0.023 . The respective share of explained variance in earnings of type of education is $16.5 \%$ within the health subsample and $36.3 \%$ within the mixed fields subsample.

In summary, the subsample analyses show that the main results of our baseline model remain unchanged. The subsample analysis for gender shows that for women, both factors are equally important in terms of variance in earnings. For men, the variance in earnings attributable to the subject area factor is three to four times larger than the variance attributable to type of education.

The subsample analyses that consider the effect of each factor on subgroups constructed based on the other factor reveal relatively high shares of explained variance attributable to subject area within the type of education subsamples. Within the sample of individuals combining vocational and academic education, subject area explains the largest share of variance in earnings.

Within subject area subsamples, the shares of explained variance in earnings attributable to type of education are relatively low. However, there are two exceptions: The first refers to the health subsample in which type of education explains a higher share of variance in earnings. The second refers to individuals combining different subject areas whose earnings vary considerably more with the type of education in which they choose to specialize. These results might indicate complementarities in combinations of different types of education and different subject areas.

\section{Conclusion}

This study is the first to demonstrate the relative importance of type of education in comparison to subject area in determining variance in earnings for highly educated individuals, i.e. individuals having a tertiary educational degree. The results show that subject area explains nearly twice the variance in earnings as that explained by type of education. Within the subsamples for type of education and subject area, the results essentially remain unchanged. One possible explanation for why earnings vary more for subject area than for type of education 
is that the market value of tasks varies more by subject areas than by type of education. Altonji et al. (2013) argue that the value of different tasks in the labor market varies considerably. As these tasks relate to specific skills and knowledge developed in different educational careers, the returns to education vary. Another explanation is that differences in the demand for different types of education are less pronounced than differences in the demand for different fields, i.e., the labor market demand for academic and for vocational qualifications differs only marginally. Future research might assess the validity of these different explanations and explicitly consider potential biases due to ability sorting or self-selection into specific subject areas or types of education.

Our analysis is of high policy relevance. As our empirical evidence shows that variance in earnings - and thereby risk - relate more to subject area than to type of education, an evidence based decision of individuals caring about the risk of their educational decision should care more about the selection of a specific subject area than the choice between vocational and academic educational tracks (which caught most of the attention in the past). Educational decisions as part of HRM policies should also devote as much attention to the choice of subjects or occupations as to the types of education, i.e. vocational or academic. This is especially important for companies or countries planning to introduce or to extend vocational education as part of their human resources strategies.

In addition, our results show that a combination of vocational and academic education has high returns as well as low variances. Hence, permeability between the two tracks, i.e., the opportunity to combine academic and vocational educations, appears to be a critical factor, as potential complementarities might exist between different types of education. 


\section{References}

Altonji, J.G., Blom, E. and Meghir, C. (2012), "Heterogeneity in human capital investments: high school curriculum, college major, and careers", Annual Review of Economics, Vol. 4 No. 1, pp. 185-223.

Backes-Gellner, U. and Moog, P. (2013), "The disposition to become an entrepreneur and the jacks-ofall-trades in social and human capital", Journal of Socio-Economics, Vol. 47, pp. 55-72.

Backes-Gellner, U., Tuor, S.N. and Wettstein, D. (2010), "Differences in the educational paths of entrepreneurs and employees", Empirical Research in Vocational Education and Training, Vol. 2 No. 10, pp. 83-105.

Bishop, J.H. and Mane, F. (2004), "The impacts of career-technical education on high school labor market success", Economics of Education Review, Vol. 23 No. 4, pp. 381-402.

Bonin, H., Dohmen, T., Falk, A., Huffman, D. and Sunde, U. (2007), "Cross-sectional earnings risk and occupational sorting: the role of risk attitudes”, Labour Economics, Vol. 14 No. 6, pp. 926-37.

Christiansen, C., Joensen, J.S. and Nielsen, H.S. (2007), "The risk-return trade-off in human capital investment”, Labour Economics, Vol. 14 No. 6, pp. 971-86.

Conlon, G. (2005), "The determinants of undertaking academic and vocational qualifications in the United Kingdom”, Education Economics, Vol. 13 No. 3, pp. 299-313.

Dearden, L., McIntosh, S., Myck, M. and Vignoles, A. (2002), "The returns to academic and vocational qualifications in Britain", Bulletin of Economic Research, Vol. 54 No. 3, pp. 249-74.

Del Rossi, A.F. and Hersch, J. (2008), "Double your major, double your return?", Economics of Education Review, Vol. 27 No. 4, pp. 375-86.

Dickson, M. and Harmon, C. (2011), "Economic returns to education: what we know, what we don't know, and where we are going - some brief pointers", Economics of Education Review, Vol. 30, $1118-22$.

Eugster, B., Lalive, R., Steinhauer, A. and Zweimüller, J. (2011), "The demand for social insurance: does culture matter?", The Economic Journal, Vol. 121, pp. F413-F448.

Federal Office for Professional Education and Technology (OPET) (2009), Die Schweizer Fachhochschulen, OPET, Berne.

Federal Statistical Office (FSO) (2013), Maturitäten und Übertritte an Hochschulen 2012, Statistik der Schweiz, Fachbereich 15, Bildung und Wissenschaft, FSO, Neuchâtel.

Federal Statistical Office (FSO) (2003), Handbuch zur Berufsdatenbank, FSO, Neuchâtel.

Finnie, R. and Frenette, M. (2003), "Earning differences by major field of study: evidence from three cohorts of recent Canadian graduates", Economics of Education Review, Vol. 22 No. 2, pp. 179-92.

Geel, R. and Backes-Gellner, U. (2011), "Career entry and success after tertiary vocational education", working paper no. 52, Swiss Leading House "Economics of Education”, Berne/Zurich, January.

Gerfin, M., Leu, R.E. and Nyffeler, R. (2003), „Berufliche Weiterbildung in der Schweiz“, discussion paper no. 03-18, Department of Economics, University of Berne, Berne, October.

Glocker, D. and Storck, J. (2014), "Risks and returns to educational fields - a financial asset approach to vocational and academic education", Economics of Education Review, Vol. 42, pp. 109-29. 
Harmon, C., Hogan, V. and Walker, I. (2003), "Dispersion in the economic return to schooling", Labour Economics, Vol. 10 No. 2, pp. 205-14.

Harmon, C., Oosterbeek, H. and Walker, I. (2003), "The returns to education: microeconomics", Journal of Economic Survey, Vol. 18 No. 2, pp. 115-55.

Hartog, J. (2011), A risk augmented Mincer earnings equation? Taking stock. Research in Labor Economics.

Hartog, J. and Vijverberg, W.P. (2007), "On compensation for risk aversion and skewness affection in wages”, Labour Economics, Vol. 14 No. 6, pp. 938-56.

Heijke, H. and Koeslag, M. (1999), "The labour-market position of university education and higher vocational education in economics and business administration: a comparison", Education Economics, Vol. 7 No. 3, pp. 259-76.

Hemelt, S.W. (2010), "The college double major and subsequent earnings", Education Economics, Vol. 18 No. 2, pp. 167-89.

Hoeckel, K., Field, S., Justesen, T. and Kim, M. (2010), Learning for Jobs, OECD Review of Vocational Education and Training, OECD, Paris.

International Labour Organization (ILO) (2008), Resolution Concerning Updating the International Standard Classification of Occupations, ILO, Geneva.

Janssen, S., Tuor Sartore, S. and Backes-Gellner, U. (forthcoming), "Social attitudes on gender equality and firms' discriminatory pay-setting", Industrial and Labor Relations Review.

Kang, S. and Bishop, J. (1989), "Vocational and academic education in high school: complements or substitutes?", Economics of Education Review, Vol. 8 No. 2, pp. 133-48.

Koerselman, K. and Uusitalo, R. (2014), "The risk and return of human capital investments", Labour Economics, Vol. 30, pp. 154-63.

Mincer, J. (1974), Schooling, Experience, and Earnings, National Bureau of Economic Research, New York, NY.

Pereira, P.T. and Martins, P.S. (2004), „Returns to education and wage equations“, Applied Economics, Vol. 36 No. 6, pp. 525-31.

Rumberger, R.W. and Thomas, S.L. (1993), "The economic returns to college major, quality and performance: a multilevel analysis of recent graduates", Economics of Education Review, Vol. 12 No. 1, pp. 1-19.

Ryan, P. (2001), "The school-to-work transition: a cross-national perspective", Journal of Economic Literature, Vol. 39, pp. 34-92.

Schweri, J., Hartog, J. and Wolter, S. C. (2011), "Do students expect compensation for wage risk?", Economics of Education Review, Vol. 30 No. 1, pp. 215-227

Swiss Confederation (2011), Federal Act on Funding and Coordination of the Swiss Higher Education Sector (HFKG) of September 30, 2011, Art. 2 \& 26, Swiss Confederation, Berne.

Swiss Coordination Centre for Research in Education (SCCRE) (2014). Swiss Education Report 2014, SCCRE, Aarau.

Swiss Coordination Centre for Research in Education (SCCRE) (2010), Swiss Education Report 2010, SCCRE, Aarau. 
Swiss Coordination Centre for Research in Education (SCCRE) (2007), Bildungsbericht Schweiz 2006, 2nd ed., SCCRE, Aarau.

Thomas, S.L. (2000), "Deferred costs and economic returns to college major, quality, and performance", Research in Higher Education, Vol. 41 No. 3, pp. 281-313.

Thomas, S.L. and Zhang, L. (2005), "Post-baccalaureate wage growth within four years of graduation: the effects of college quality and college major", Research in Higher Education, Vol. 46 No. 4, pp. 437-59.

Tuor, S.N. and Backes-Gellner, U. (2010), "Risk-return trade-offs to different educational paths: vocational, academic and mixed", International Journal of Manpower, Vol. 31 No. 5, pp. 495-519.

Wolter, S.C. and Weber, B.A. (1999), "A new look at private rates of return to education in Switzerland", Education + Training, Vol. 41 No. 8, pp. 366-72. 


\section{Appendix: The Swiss Educational System}

After nine years of compulsory schooling, students aged approximately 15 and 16 choose either a vocational or an academic upper-secondary education. Approximately $60 \%$ of all Swiss students choose a dual-track vocational education and training (VET) program (SCCRE 2010, p. 112). These programs combine on-the-job training, in the form of a paid apprenticeship in a host company, with theoretical teaching at school. Graduates receive an "Advanced Federal Certificate" and continue working as skilled workers within their respective occupational fields, either in the training company or a new one (Tuor and Backes-Gellner, 2010, p. 498). ${ }^{17}$

\section{Figure A1: The Swiss Educational System}

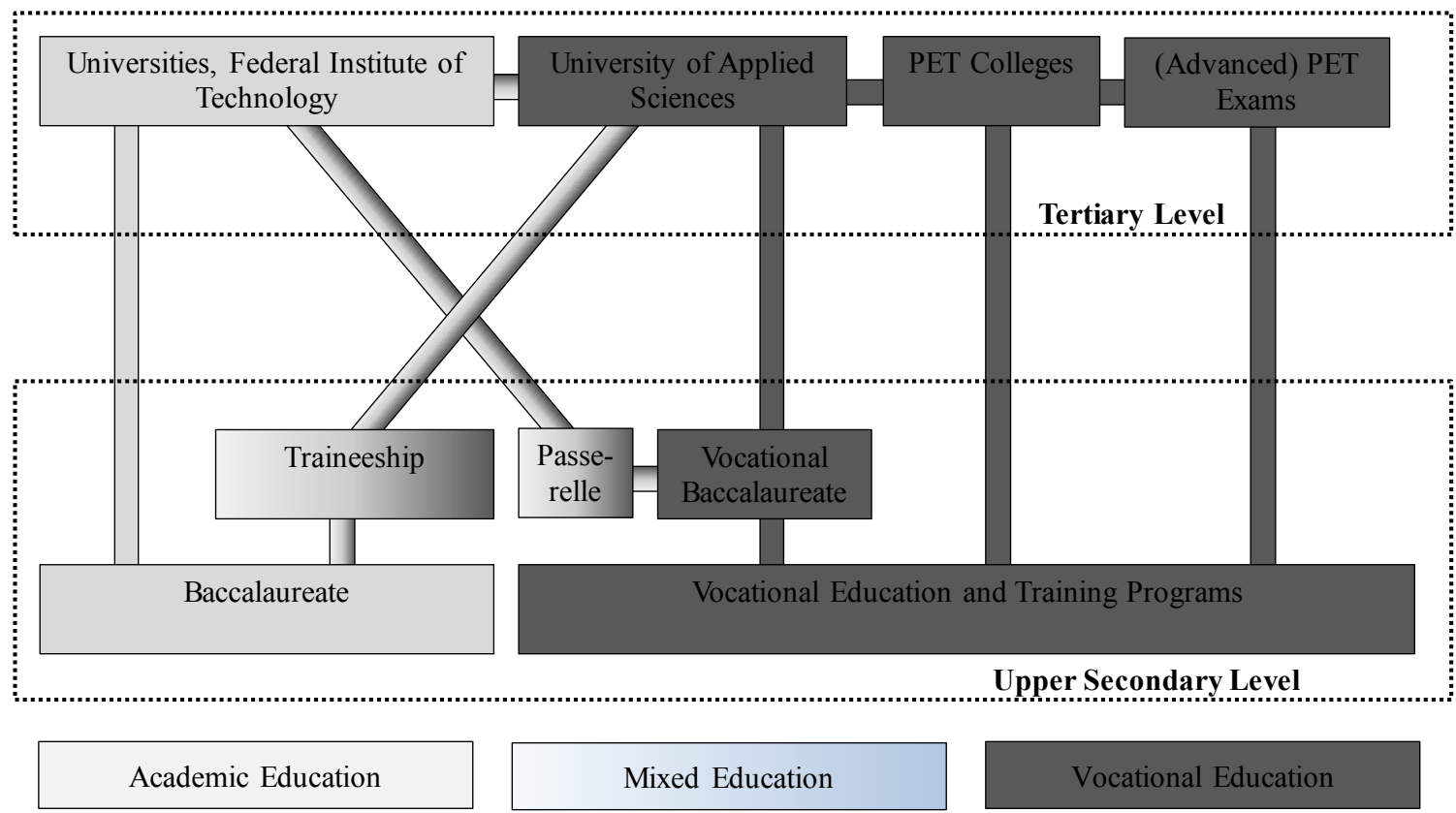

Source: Own illustration, based on SCCRE (2007, 2010, 2014).

\footnotetext{
${ }^{17}$ Beyond these apprenticeships, an additional $10 \%$ of students attend full-time VET schools after compulsory education. Less than $5 \%$ of all students attend an upper-secondary specialized school (SCCRE, 2010, p. 17). Fulltime VET schools do not offer work-based training, a characteristic peculiar to apprenticeship programs. Uppersecondary specialized schools provide both extensive general educations and occupation-specific knowledge to prepare students for further professional education and training at the tertiary vocational level. In addition, uppersecondary specialized schools offer an upper-secondary specialized baccalaureates for specific occupations.
} 
Individuals with an upper-secondary vocational degree have several options for tertiary education. On the one hand, they can continue to follow the vocational track because the Swiss educational system offers a variety of opportunities with different objectives. First, individuals having obtained a federal vocational baccalaureate during or after an upper-secondary VET program have access to universities of applied science. While these universities of applied science and conventional universities are of equal status, their focus in terms of teaching and research differ. Universities of applied science emphasize practically oriented and applied research and development. Therefore, the studies they offer focus on practice, include general vocational training, and prepare their students for occupations that require the application of scientific knowledge and methods.

Second, VET graduates can acquire necessary competencies in demanding occupational activities or activities with high responsibilities through professional education and training (PET) colleges. PET colleges provide nationally approved core curricula that enhance technical and managerial expertise in the student's occupational field. The admission requirements are a VET, federal vocational baccalaureate or baccalaureate degree as well as a certain amount of professional experience and/or a goal score on an aptitude test.

Third, federal professional education and training diploma examinations and advanced federal professional education and training diploma examinations ("Meisterprüfung") constitute another tertiary vocational education option. These examinations assess whether candidates are able to perform demanding management-related or technical activities. Advanced federal professional education and training diploma examinations are more challenging, as they test the candidate's field expertise or his or her ability to independently manage a small- or medium-sized business. Eligibility requirements for the examinations are the equivalent of those of PET colleges. However, in contrast to PET college curricula, the curricula for these examinations are not nationally approved. Only the mode and content of the examinations are federally recognized.

On the other hand, individuals with a VET degree have access to academic tertiary education in combination with a good score on the University Aptitude Test. Approximately $3 \%$ of the 2006 cohort of upper-secondary students with federal vocational baccalaureate degrees entered a tertiary academic institution in this manner (Federal Statistical Office, 2013, p. 9). In addition, students possessing a bachelor's degree from a university of applied sciences can begin a master's degree program at a conventional academic institution at the tertiary level. 
In contrast to other Western countries, only approximately $20 \%$ of Swiss students completing compulsory schooling choose the academic track, i.e., obtain a baccalaureate (SCCRE 2010, p. 17). This baccalaureate allows its holders unrestricted access to all tertiary academic institutions in Switzerland, i.e., universities and federal institutes of technology. Moreover, if they complete a traineeship in their intended field of study, individuals with a baccalaureate degree also have access to universities of applied sciences.

Figure A1 illustrates the Swiss educational system. ${ }^{18}$ It shows that the system provides vocational and academic education at the upper-secondary and tertiary levels and allows for permeability between and within the two levels.

\footnotetext{
${ }^{18}$ Neither universities of teacher education nor upper-secondary specialized schools are included in the illustration, as these institutions are not relevant to our analysis.
} 